\title{
Laffer Curves and Home Production ${ }^{* *}$
}

DOI 10.1515/ntaxj-2017-0004

Received Dec 17, 2016; accepted Mar 03, 2017

\begin{abstract}
In the earlier related literature, consumption tax rate Laffer curve is found to be strictly increasing (see Trabandt and Uhlig (2011)). In this paper, a general equilibrium macro model is augmented by introducing a substitute for private consumption in the form of home production. The introduction of home production brings about an additional margin of adjustment - an increase in consumption tax rate not only decreases labor supply and reduces the consumption tax base but also allows a substitution of market goods with home-produced goods. The main objective of this paper is to show that, after the introduction of home production, the consumption tax Laffer curve exhibits an inverse U-shape. Also the income tax Laffer curves are significantly altered. The result shown in this paper casts doubt on some of the earlier results in the literature.
\end{abstract}

Keywords: Taxation, Laffer curve, Consumption, Homeproduction

\section{Introduction}

Laffer curve is a mapping that defines how aggregate tax revenue evolves as a function of a tax rate. The original idea by Arthur Laffer was that there are always two tax rates that yield the same revenues. In other words, at some tax rate, the negative incentive effects become large enough and a marginal increase in tax rate will end up lowering the aggregate tax accrual. The policy implication in such situation is apparent: a government maximizing its tax revenue should lower the tax rate instead of increasing it.

\footnotetext{
^Corresponding Author: Mauri Kotamäki: Finnish Pension Alliance, Helsinki, Finland; Email: Makota@utu.fi

$\star \star$ I'm grateful to the editor Seppo Kari and the two anonymous referees for valuable comments. I would also like to thank Mika Kuismanen, Tuomas Matikka and the participants of $33^{\text {rd }}$ Summer Seminar of Finnish Economists.
}

A number of questions then arise. Is the current economy on the left or right side of the Laffer curve's peak? And how far is the revenue maximizing tax rate, that is, what is the fiscal space? In a seminal paper, Trabandt and Uhlig (2011) characterize Laffer curves for the United States and a number of European countries using a neoclassical general equilibrium framework. The results show that the peak, that is, the revenue maximizing tax rate, of the (labor income) Laffer curve is located between tax rates of 55\% and $68 \%$, depending on the country. Furthermore, the authors find that the labor and capital income Laffer curves exhibit an inverse U-shape, whereas the consumption Laffer curve is strictly increasing. This is an interesting result as both labor income and consumption taxes tax market work, thus, it could be expected that also the consumption Laffer curve was hump-shaped. The authors show, however, that the negative incentive effects of a consumption tax hike are never large enough to bend the consumption Laffer curve onto a declining path. This is the point of interest of this paper. What are the mechanisms that affect the shape of the Laffer curve? What mechanism makes labor and capital income Laffer curves hump shaped but consumption Laffer curve strictly increasing?

This paper dwells into one mechanism that has influence on Laffer curves - home production. It turns out that a substitute for market consumption, home production in this case, has a significant impact on Laffer curves, thus bringing some uncertainty on the existing Laffer curve estimates. In a "traditional" model, an increase in consumption tax rate reduces consumption tax base, but the negative effect is usually small - in the aggregate, tax revenue increases as a result of a tax hike, therefore, a strictly increasing Laffer curve. Adding home production into the model changes this mechanism by accelerating the deterioration of the tax base compared to the traditional model, because a consumption tax hike, additionally, induces agents to substitute market-based consumption with home-produced goods. The result of strictly increasing consumption Laffer curve breaks down.

Recently, at least Trabandt and Uhlig (2011), Trabandt and Uhlig (2012), Feve et al. (2013), Holter et al. (2014), Zanetti (2012), Nutahara (2013), and Auray et al. (2015) have considered taxation and Laffer curves from various 
perspectives. ${ }^{1}$ In all the papers, the model specification is such that there is no substitute for market consumption, which typically implies that the Laffer curve is strictly increasing with the consumption tax rate. In a recent paper, Hiraga and Nutahara (2016) derive the necessary conditions with certain utility function specifications that yield a hump shaped consumption tax Laffer curves. The authors show that Laffer curve for consumption tax rate can be hump shaped if the utility function is additively separable in consumption and labor supply and, on the other hand, it cannot be hump shaped if the utility function is non separable. In this paper, it is shown that the result by Hiraga and Nutahara (2016) breaks down when home production is introduced into the model.

This result of monotonically increasing Laffer curve for consumption tax, which stems from the often used model specification, can be questioned. When the relative prices change, individuals do not adjust only the leisureconsumption relation, but also the composition of consumption can change.

One example of a compositional change in consumption is home production. If the relative price of marketproduced goods increases (e.g., consumption tax rate increases), it becomes more attractive to produce certain goods and services at home. As a consequence, some people at the margin move from market-based consumption toward home-produced goods consumption. There can also be other types of compositional changes in consumption. An increase in the tax of a typical consumption good can induce a greater demand for black market goods or imported (tax-free) goods. This paper concentrates on home production, but it should be kept in mind that similar mechanism works also for other consumption substitutes.

There is a considerable research literature on the economics of home production. Furthermore, home production has also been studied in the context of taxation - the relevant context for this paper. Holmlund (2002) studies the effects of labor taxes on labor market outcomes in a model of equilibrium unemployment. He finds that home production brings the basic search equilibrium model of labor market closer to reality so that the neutrality result of proportional tax rate on employment disappears with the introduction of home production.

Engström et al. (2001) explore tax differentiation between (physical) goods and services in a labor market search and matching model with home production. The authors show that a tax cut on service sector reduces unemployment and also that the introduction of sectoral tax

1 See Kotamäki (2015) for a brief treatment of these papers. differentiation with lower tax on services is welfare improving.

Olovsson (2009) argues that home production can explain most of the differences in labor supply between the United States and Europe. Including home production in the model of economic behavior, Olovsson (2009) shows that the total amount of work only differs by $1 \%$ between Sweden and the United States. With this paper, the author participates in wider discussion in which Prescott (2004) argues that, virtually, all differences in labor supply between the United States and Europe are due to differences in tax systems. Prescott has been, however, criticized by many because the labor supply elasticities he found are higher than what have been found in the previous literature. Olovsson's contribution is to show that when home production is included in the model, the difference between the United States and Europe in labor supply can be explained irrespective of the magnitude of labor supply elasticity, and one possible explanation is home production.

In another recent paper, Olovsson (2015) argues that it is important that the government takes home production into account when designing the tax system. The author derives optimal consumption tax rate, which shows (among other things) that the optimal tax rate on market services is lower than the tax rate on market goods. The intuition is the following. Taxation of labor income is distortionary, and in order to minimize this distortion, a strictly positive tax on leisure (including home production) should be set. It is not, however, possible to tax home production directly, but decreasing taxes on market services is equivalent to increasing taxes on home production when home production and market services are substitutes.

Vogel (2012) uses a large-scale open-economy NewKeynesian DGE model to study the effect of home production on tax revenue. His findings are somewhat contrary to the findings of this paper. According to Vogel (2012), Laffer peak (or "fiscal limit") isn't much affected when home production is introduced to the model. The author does find, similar to the results of this paper, that the substitution of home work and market work has a clear impact. Also the assumption regarding home production function seems to be important.

On the empirical side, Rupert et al. (2000) argue that neglecting home production can lead to downwards biased estimates of the intertemporal labor supply elasticity. The result is in many ways potentially important, not least because higher the labor supply elasticity, the greater is the welfare loss of taxation. 
In summation, the previous theoretical literature has found the presence home production to have important effect on both the magnitude and even the direction of results. Furthermore, not only the theoretical literature but also empirical literature confirms that home production plays an important role in the individual decision making. This paper attempts to explain the somewhat strange behavior of Laffer curves with the absence of substitute for market consumption by augmenting the standard model with home production. It is found that the previous results are altered with this addition.

This paper is organized as follows. Section 2 describes the model used in this paper. Section 3 presents the results in tax revenue curves (Laffer curves). Section 4 conducts a sensitivity analysis on the results. Section 5 concludes.

\section{The Model}

The model used in this paper is a standard general equilibrium model along the Baxter and King (1993) tradition. The main difference to the standard model is the introduction of home production as a substitute for market-produced goods.

The model economy, presented in more detail in the following, consists of a large number of identical agents and firms and a government. In this paper, only steady state, that is, the long-run equilibrium, is analyzed. A representative agent consumes goods, produces goods for his or her own consumption, works, and saves in the form of capital and government bonds. Firms produce goods using capital and labor as factors of production. The government collects capital, consumption, and labor income taxes and issues bonds to finance its consumption, transfer payments, and debt services.

\subsection{Individuals}

A representative individual chooses consumption $\left(c_{t}\right)$, hours worked $\left(n_{t}\right)$, capital stock $\left(k_{t}\right)$, private investment $\left(i_{t}\right)$, and government bond holdings $\left(b_{t}\right)$ in order to maximize his or her discounted expected utility. Utility is derived from consumption and leisure $\left(1-n_{t}\right)$. The representative agent maximizes

$$
U_{t}=\max E_{0} \sum_{t=0}^{\infty} \beta^{t} u\left(c_{t}, 1-n_{t}\right)
$$

subject to

$$
\left(1+\tau_{t}^{c}\right) c_{t}^{m}+i_{t}+b_{t}=\left(1-\tau_{t}^{n}\right) w_{t} n_{t}^{m}
$$

$$
\begin{aligned}
& +\left(1-\tau_{t}^{k}\right)\left(r_{t}^{k}-\delta\right) k_{t} \\
& +\delta k_{t}+\left(1+r_{t}^{b}\right) b_{t-1}+s_{t}+\Pi_{t}, \\
k_{t+1} & =(1-\delta) k_{t}+i_{t},
\end{aligned}
$$

where $\beta \in(0,1)$ is the utility discount rate, $c_{t}^{m}$ is the consumption of market goods, $n_{t}^{m}$ denotes the labor supplied to the market, and $\tau_{t}^{c}, \tau_{t}^{n}$ and $\tau_{t}^{k}$ denote the consumption, labor, and capital tax rates, respectively. On the income side, $w_{t}$ denotes wage rate, $s_{t}$ the government transfers, $\Pi_{t}$ the profits of the firms, and $r_{t}^{k}$ and $r_{t}^{b}$ the interest rate applied to capital and government bonds, respectively. Profits equal zero in the equilibrium with perfect competition. Total hours worked is the sum of hours worked in the market sector and hours worked in home production: $n_{t}=$ $n_{t}^{m}+n_{t}^{h}$. The capital depreciation rate is given by $\delta$.

A representative agent derives utility from a composite consumption good:

$$
c_{t}=\left(\omega\left(c_{t}^{m}\right)^{\kappa}+(1-\omega)\left(c_{t}^{h}\right)^{\kappa}\right)^{1 / \kappa},
$$

where the superscripts $m$ and $h$ denote the market goods and home-produced goods, respectively. The parameter $\omega$ denotes the share of market-produced goods in private consumption, and $\kappa$ measures the elasticity of substitution between home- and market-produced goods. Equation (4) is important in terms of results, and thus, a more detailed inspection of it is in order. Take a total differential of equation (4) and hold the composite consumption constant by setting $d\left(c_{t}\right)=0$. The resulting equation is given as follows:

$$
\frac{d\left(c_{t}^{m}\right)}{c_{t}^{m}}=-\frac{(1-\omega)}{\omega}\left(\frac{c_{t}^{h}}{c_{t}^{m}}\right)^{\kappa} \frac{d\left(c_{t}^{h}\right)}{c_{t}^{h}} .
$$

Equation (5) states that, conditional on $c_{t}$, individual is willing to substitute market consumption with home production as a function of $\omega$ and $\kappa$. A change in economic environment, for example, an increase in consumption tax, induces individual to substitute market-produced goods with home-produced goods. In Figure 1, an isoconsumption curve is drawn (holding $c_{t}$ constant), illustrating the trade-off between $c_{t}^{m}$ and $c_{t}^{h}$.

Continuing with the model description, there is a production function, which defines the production technology of home-produced goods. Olovsson (2015) assumes a production function that uses home capital and home work as production inputs. Rogerson and Wallenius (2012), on the other hand, assume a functional form that combines market-purchased goods and home production time as inputs of home production. For simplicity and 


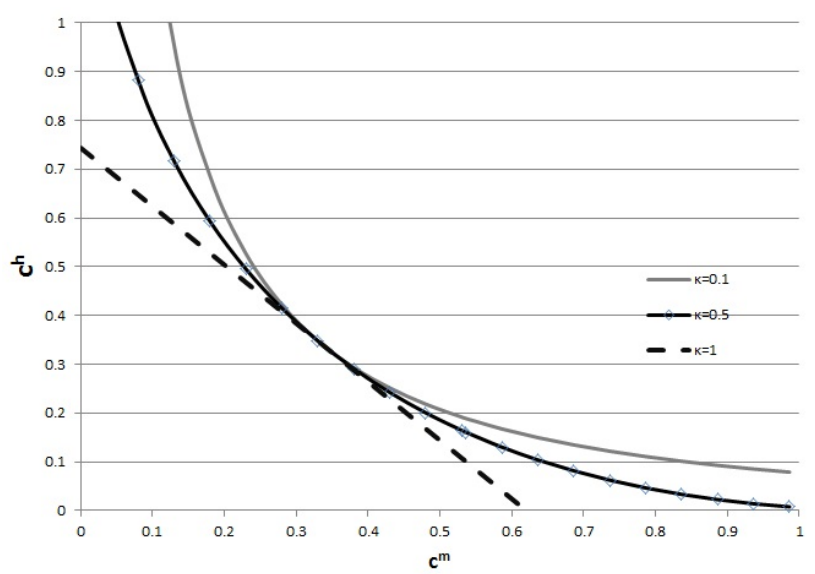

Figure 1: Consumption holding $c_{t}$ constant

transparency, more along the lines of Olovsson (2009), a following form of home production function is assumed:

$$
c_{t}^{h}=\left(n_{t}^{h}\right)^{\alpha^{h}}
$$

The periodic utility function is increasing and concave in consumption and leisure and assumed to be of the following form:

$$
u\left(c_{t}, 1-n_{t}\right)=\frac{\left(c_{t}\right)^{1-\sigma}\left(1-\gamma(1-\sigma) n_{t}^{1+1 / \phi}\right)^{\sigma}-1}{1-\sigma},
$$

where $\phi, \sigma$, and $\gamma$ denote, respectively, Frisch elasticity of labor supply, measure of intertemporal elasticity of substitution $(\neq 1)$, and a scale parameter for dis utility of labor. Utility function of this form features a constant Frisch elasticity of labor supply, which is convenient in this type of analysis, because the magnitude of the labor supply elasticity is important in terms of results. Particularly, this type of utility function is relevant, because it allows comparisons to the related research. A more in-depth treatment of a utility function of this specification is given in Trabandt and Uhlig (2011).

The first-order conditions of the household's optimization are as follows:

$$
\begin{gathered}
\frac{\partial u(.)}{\partial n_{t}^{m}}=-\frac{\partial u(.)}{\partial c_{t}} \frac{\partial c_{t}}{\partial c_{t}^{m}} \frac{\left(1-\tau_{t}^{n}\right)}{\left(1+\tau_{t}^{c}\right)} w_{t} \\
\frac{\partial u(.)}{\partial n_{t}^{h}}=-\frac{\partial u(.)}{\partial c_{t}} \frac{\partial c_{t}}{\partial n_{t}^{h}} \\
\frac{1}{\left(1+\tau_{t}^{c}\right)} \frac{\partial u(.)}{\partial c_{t}} \frac{\partial c_{t}}{\partial c_{t}^{m}}= \\
\beta E_{t}\left[\frac{1}{\left(1+\tau_{t+1}^{c}\right)} \frac{\partial u(.)}{\partial c_{t+1}} \frac{\partial c_{t+1}}{\partial c_{t+1}^{m}}\left(1+\left(1-\tau_{t+1}^{k}\right)\left(r_{t+1}^{k}-\delta\right)\right)\right]
\end{gathered}
$$

$$
\begin{aligned}
& \frac{1}{\left(1+\tau_{t}^{c}\right)} \frac{\partial u(.)}{\partial c_{t}} \frac{\partial c_{t}}{\partial c_{t}^{m}}= \\
& \beta E_{t}\left[\frac{1}{\left(1+\tau_{t+1}^{c}\right)} \frac{\partial u(.)}{\partial c_{t+1}} \frac{\partial c_{t+1}}{\partial c_{t+1}^{m}}\left(1+r_{t+1}^{b}\right)\right] .
\end{aligned}
$$

Equation (8) characterizes the labor supply decision of an individual in the labor market, equation (9) determines the labor supply in home production, and finally, equations (10) and (11) determine the equilibrium rate of return for capital and guarantee that there are no arbitrage opportunities between the rate of return for capital and government bonds, that is, $\left(1-\tau_{t}^{k}\right)\left(r_{t}^{p}-\delta^{p}\right)=r_{t}^{b}$.

\subsection{Firms}

There is a large number of identical final good firms that produce a homogeneous product by choosing $k_{t}$ and $n_{t}^{m}$. The firms maximize their profits, which are given by the following:

$$
\Pi_{t}=y_{t}-r_{t}^{k} k_{t}-w_{t} n_{t}^{m}
$$

Output, $y_{t}$, of a representative final good firm is given by

$$
y_{t}=A_{t}\left(k_{t}\right)^{\alpha}\left(n_{t}^{m}\right)^{1-\alpha},
$$

where $A_{t}=\left(1+g^{A}\right) A_{t-1}$ is the total factor productivity, $g^{A}$ denotes the trend growth of the total factor productivity, $\alpha$ and $(1-\alpha)$ are the share parameters of private capital and labor, respectively. The rental rate of private capital and wage rate are, respectively, given by

$$
\begin{gathered}
r_{t}^{k}=\frac{\partial y_{t}}{\partial k_{t}}, \\
w_{t}=\frac{\partial y_{t}}{\partial n_{t}^{m}} .
\end{gathered}
$$

\subsection{Government}

The government collects taxes, $T_{t}$, and issues bonds $\left(b_{t}\right)$ in order to finance expenditures for government consumption $\left(g_{t}\right)$, investments $\left(i_{t}^{g}\right)$, transfers $\left(s_{t}\right)$, and debt services:

$$
\begin{aligned}
& T_{t}=\tau_{t}^{c} c_{t}^{m}+\tau_{t}^{n} w_{t} n_{t}^{m}+\tau_{t}^{k}\left(r_{t}^{k}-\delta\right) k_{t}, \\
& g_{t}+i_{t}^{g}+s_{t}+\left(1+r_{t}^{b}\right) b_{t-1}=b_{t}+T_{t} .
\end{aligned}
$$

The no-ponzi constraint of public sector debt must apply:

$$
\lim _{T \rightarrow \infty}\left(\frac{b_{T+1}}{\prod_{j=1}^{T}\left(1+r_{j}^{b}\right)}\right)=0 .
$$


The no-ponzi condition states that the discounted stream of taxes must equal the current value of outstanding government debt plus stream of government expenditures. Public debt has no specific role in the analysis apart from making the government budget constraint more realistic.

It is necessary to have one "adjusting" or endogenous variable in the government budget constraint in order to have a well-behaving system of model equations. Following a standard practice in the literature, when taxes, government consumption, or debt is altered, government adjusts transfers $\left(s_{t}\right)$ according to the government budget constraint. ${ }^{2}$ More specifically, variable called "transfers" represents a residual term of government budget constraint and is given as follows:

$$
s_{t}=b_{t}+T_{t}-g_{t}-i_{t}^{g}-\left(1+r_{t}^{b}\right) b_{t-1} .
$$

The endogeneity of $s_{t}$ is important in terms of results and some observations are in order. First, the results of this paper do not change if the public debt $\left(b_{t}\right)$ is made endogenous instead of $s_{t}$ - the Ricardian equivalence typically holds in this type of models.

Second, the results change if the government consumption $\left(g_{t}\right)$, which is assumed to be waste, is made the endogenous variable. Endogenizing government consumption shifts the Laffer peak to the right, because there is no (negative) income effect on labor supply via government transfers.

Third, and related to the previous point, the effect of utility producing government consumption or productive public capital is not explored in this paper. It is possible, however, that the inclusion of such mechanism would increase fiscal space, because the negative effect of a tax increase was mitigated by a positive effect on utility or production.

\subsection{General Equilibrium}

In the competitive (decentralized) equilibrium, individuals maximize their utility, firms maximize profits, all constraints are satisfied, and all markets are clear. Specifically, general equilibrium is the path of endogenous variables $\left\{y_{t}, c_{t}, c_{t}^{m}, c_{t}^{h}, n_{t}^{m}, n_{t}^{h}, k_{t}, i_{t}, r_{t}^{k}, r_{t}^{b}, w_{t}, T_{t}, s_{t}, \Pi_{t}\right\}$ that satisfies the individual budget constraint (2), law of motion for capital (3), equation defining composite consumption (4), individual first-order conditions (8)-(11),

2 Trabandt and Uhlig (2011) call this the s-Laffer curve, whereas the $\mathrm{g}$-Laffer curve is the one where government consumption $\left(g_{t}\right)$ is endogenous. production technology for market goods (12) and homeproduced goods (6), factor price equations (13) and (14), and the characterization of government (15)-(17), given the exogenous variables such as government consumption $\left(g_{t}\right)$, government investment $\left(i_{t}^{g}\right)$, government debt $\left(b_{t}\right)$, and the tax rates $\tau_{t}^{c}, \tau_{t}^{n}$ and $\tau_{t}^{k}$.

\section{Results}

\subsection{Benchmark Calibration}

The model is calibrated to match the essential features of the Finnish economy. The data used is of annual frequency, and the period of interest is post-2008 to capture the recent challenges in the economic environment, particularly the deteriorated fiscal position of the economy since 2009.

There are a number of parameters to be calibrated. Following the usual practice, as many parameters as possible are calibrated using evidence from existing research literature, and the rest are set to match certain ratios in the data. All the calibrated values of parameters and exogenous variables are reported in Tables 1 and 2.

Table 1: Calibration of Parameters

\begin{tabular}{cl}
\hline Parameter & Value \\
\hline$\gamma^{A}$ & 0.009 \\
$\phi$ & 0.82 \\
$\alpha$ & 0.349 \\
$\alpha^{h}$ & 1 \\
$\delta$ & 0.060 \\
$\sigma$ & 2 \\
$\gamma$ & 2.420 \\
$\omega$ & 0.545 \\
$\beta$ & 0.969 \\
$\kappa$ & 0.5 \\
\hline
\end{tabular}

The exogenous total factor productivity, $\gamma^{A}$, is assumed to be $0.9 \%$ in accordance with the long-run scenarios of the European Commission (2015). The labor share parameter in the production function, $(1-\alpha)$, is calibrated to match the wage sum share of national income, which is, on an average, 0.611 in Finland between 2009 and 2014.

Deep preference parameters of the representative agent are $\sigma, \gamma$, and $\beta$, which represent, respectively, the measure of intertemporal elasticity of substitution, the consumption weight in utility function, and the time dis- 
count factor of the utility function. The utility discount factor, $\beta$, defines, in steady state, the real interest rate of the economy, which, in turn, is a function of capitaloutput ratio. Accordingly, $\beta$ is calibrated to match the 2009-2014 capital-output ratio of the Finnish economy, which is equal to 2.617. The consumption weight in the utility function, $\gamma$, following, for example, Cooley and Soares (1999) and Papageorgiou (2012), is set so that the average working hours matches the data. According to the Finnish Time Use Survey 2009-2010, 19\% of wake time is spent in gainful employment $\left(n_{t}^{m}\right)$, whereas $16 \%$ is spent in domestic work $\left(n_{t}^{h}\right)$, which, in turn, is used to calibrate the share parameter, $\omega$. The measure of intertemporal elasticity of substitution, or "the curvature parameter", $\sigma$, is set to equal 2, which is in line with previous related literature.

There is a lively discussion upon the "correct" value of the labor supply elasticity $(\phi)$. Values used in macroeconomic literature are typically larger than those estimated from microdata. Keane and Rogerson (2012) raise a number of important points challenging the microelasticities and argue that elasticities between 1 and 2 can be credibly supported. On the other hand, in a recent survey, Chetty et al. (2012) conclude that the microeconomic evidence of Frisch elasticity points toward intensive margin elasticity of 0.54 and extensive margin of 0.28 and macroeconomic (cross-country) evidence points towards intensive margin elasticity of 0.54 and the extensive margin 2.3. ${ }^{3}$ In the analysis of this paper, following the quasi-experimental evidence reviewed by Chetty et al. (2012), a value of 0.82 is set for the (combined) Frisch elasticity of labor supply, $\phi$.

The substitution parameter, $\kappa$, is a very important one with respect to the shape of consumption Laffer curve. There is also some empirical evidence on the value of this parameter. Aguilar et al. (2011) consider older individuals and find that the parameter value is between 0.5 and 0.6. McGrattan et al. (1997) report values between 0.4 and 0.44 . Finally, Chang and Schorfheide (2003) estimate values between 0.44 and 0.6. Referring to this evidence, the substitution parameter, $\kappa$, is set to 0.5 in the same spirit as, for instance, Rogerson and Wallenius (2012).

Exogenous variables are, as well as the parameters above, calibrated to match the 2009-2014 data, if possible. This implies that the government consumption-to-output and the debt-to-output ratios are set to, respectively, 0.243 and 0.509. Finally, the benchmark tax rates $\tau_{t}^{n}, \tau_{t}^{k}$ and $\tau_{t}^{c}$ are specified using the method developed by Mendoza et al. (1994) wherein the idea is to relate relevant tax revenue to the relevant tax base. The tax rates are interpreted

3 See Chetty et al. (2012) page 2, Table 1. to be the average effective tax rates (AETR). Naturally, the method is not able to capture the complex nature of the tax system. On an average, however, it is presumably a reasonable approximation of the reality.

Table 2: Calibration of Exogenous Variables

\begin{tabular}{cc}
\hline Variable & Value \\
\hline$g / y$ & 0.243 \\
$i g / y$ & 0.04 \\
$\tau^{c}$ & 0.239 \\
$\tau^{n}$ & 0.448 \\
$\tau^{k}$ & 0.307 \\
$b / y$ & 0.509 \\
\hline
\end{tabular}

\subsection{Steady States}

The essential steady-state values produced by the model are provided in Table 3. The baseline steady-state calibration fits the data reasonably well. The calibration given in Table 3 give rise to the Laffer curves depicted with dashed line in Figures 2-4. The regular line depicts the "traditional model," the model without home production, in other words, with identical calibration method but setting $\omega=1$. Figures 2-4 depict aggregate tax revenue $\left(T_{t}\right)$, which is normalized by the Laffer curve peak value of the model without home production. The gray vertical line marks the steady-state tax level, which is also the tax rate where the two Laffer curves cross. The figures tell a story of different mechanisms in taxation with and without home production.

Table 3: Steady State and Data Averages 2009-2013

\begin{tabular}{ccc}
\hline Variable & Model-produced value & Data value \\
\hline$c / y$ & 0.536 & 0.539 \\
$i / y$ & 0.181 & 0.182 \\
$r^{b}$ & 0.051 & $0.015^{\star}$ \\
\hline
\end{tabular}

${ }^{*}$ Average yield on 5-year government bond 2009-2014.

The Laffer curves, or aggregate tax revenue curves (see equation (15)), are calculated so that one tax instrument at a time is varied between $0 \%$ and $100 \%$, while all the other parameters and exogenous variables (including the two other tax rates) in the model are held constant (the ceteris paribus assumption). Setting one tax rate to zero does not, thus, imply tax revenue of zero, because there are still 
two other strictly positive tax rates. The Laffer curves with home production are not of the expected form and do not follow the same pattern as the Laffer curves in the earlier literature (cf. Trabandt and Uhlig (2011)).

The consumption tax Laffer curves are depicted in Figure 2 . The model without home production implies strictly increasing Laffer curve between $0 \%$ and $100 \%$ tax rates, whereas the consumption Laffer curve exhibits a hump shape when home production is included in the model. The peak of the consumption tax Laffer curve lies at $60 \%$ $(100 \%)$ with (without) home production. ${ }^{4}$

Figure 2: Consumption Tax Laffer Curves

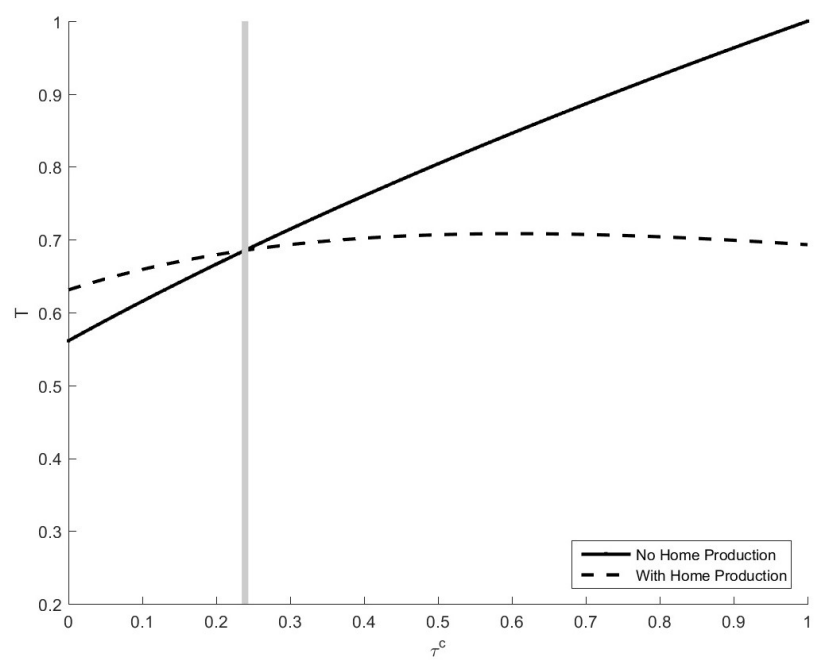

Not only the location of the Laffer peak but also the shape of the curve differs between these two specifications has significant effects on the tax revenue estimates. The average tax revenue elasticity ${ }^{5}$ with respect to consumption tax rate, that is, steepness of the aggregate tax revenue curve, is much lower in the model with home production. In both the cases, the tax revenue elasticity decreases with tax rate, but the decrease is much more pronounced with home production. Naturally, the elasticity becomes negative in the right side of the Laffer peak $(>60 \%)$, whereas

4 There is no apparent reason why the upper bound of consumption tax rate should be $100 \%$. This upper bound is imposed somewhat arbitrarily for communicational reasons.

5 Tax revenue elasticity with respect to tax rate $\tau^{i}$ is approximated with $\frac{\partial T_{t}}{\partial \tau^{i}} \approx \frac{T\left(\tau^{i}\right)-T\left(\tau^{i}-\epsilon\right)}{\epsilon}$, where $\epsilon=1 \%$ the Laffer peak is not identified in the model without home production. ${ }^{6}$

The inclusion of home production, thus, lowers the aggregate tax revenue elasticity considerably, which implies that in order to achieve a given increase in consumption tax revenue, a larger increase in tax rate is needed. On the other hand, a decrease in the tax rate is not as detrimental to the public sector revenues as is in the case without home production.

The labor income tax Laffer curves are depicted in Figure 3. The Laffer curve with (without) home production is increasing up to $35 \%$ (57\%), implying that the Finnish economy is in the "wrong" side of the Laffer peak with home production but on the "right" side without home production in the model. The recommended policy advice in terms of tax revenue, thus, depends crucially on whether or not home production is included in the model. In terms of maximizing the aggregate tax revenue, labor income tax rate should be decreased (increased) in order to maximize tax revenue with (without) home production in the model.

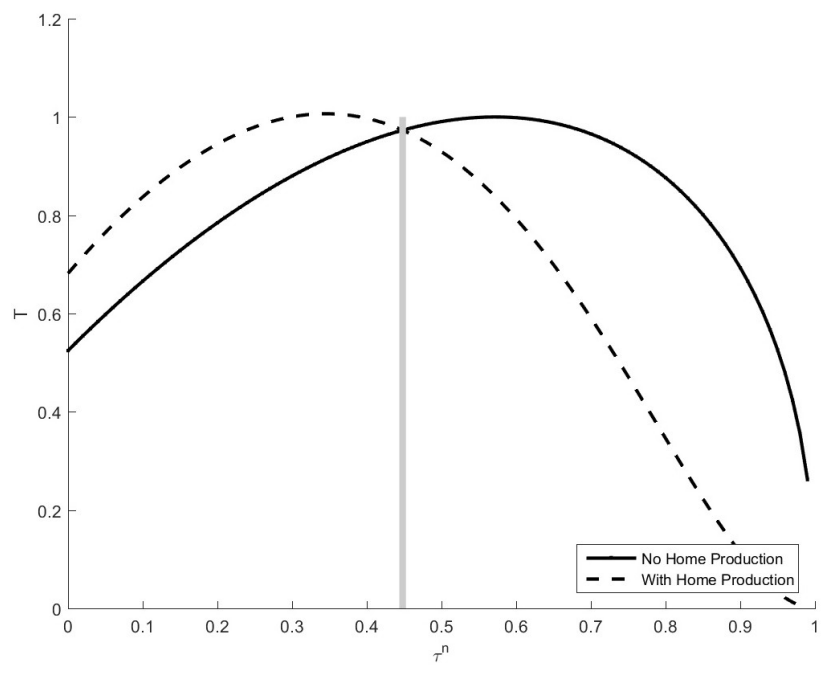

Figure 3: Labor Income Tax Laffer Curves

Finally, Figure 4 depicts capital tax rate Laffer curves. The two curves are of completely different form. The Laffer curve is strictly decreasing with home production, while without home production, it increases up to the tax rate of $29 \%$, after which it decreases rather abruptly. In both the cases, the capital Laffer curve is flatter than labor income

6 It is possible that the use of complement for labor in home production might mitigate the result depicted in Figure 2. 
or consumption tax Laffer curve, implying lower tax revenue elasticity in the flat part of the curve. Increasing the capital tax rate from $0 \%$ to $29 \%$ would lead, in the steadystate equilibrium, to a $-3.0 \%(1.7 \%)$ change in aggregate tax revenue with (without) home production. In general, the impact of capital taxation on aggregate tax revenue is clearly smaller than that of labor income or consumption taxation.

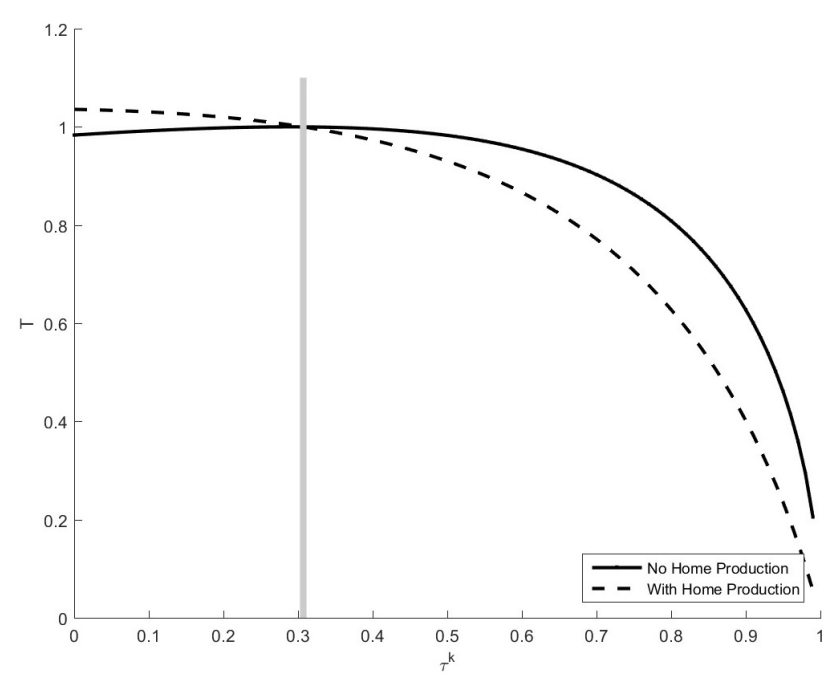

Figure 4: Capital Income Tax Laffer Curve

The reasoning behind the not so familiar looking Laffer curves is the following. With home production in the model, compared to a model without it, there is an additional margin of adjustment (see equation (9)). Suddenly individuals do not alter only labor supply (see equation (8)) in response to a tax change, but directly also consumption. Equation (9) ensures that the marginal utility of consuming market-produced goods and home-produced goods equalizes.

When the consumption tax rate increases, consumption of market goods becomes relatively more expensive and labor supply adjusts according to the intra-temporal Euler condition (see equation (8)), which lowers the disposable wage income and, consequently, has a negative effect on consumption. This is the traditional effect of a consumption tax change. Furthermore, also the marginal utilities from market consumption and home production must equalize. In this case, if there is a tax hike, home production becomes relatively more attractive and home production increases in detriment to market consumption. The outcome is that the consumption tax base deteriorates more quickly as the tax rate increases, thus, making a crucial difference in the shape of the Laffer curve. In other words, inclusion of home production brings forth a mechanism that accelerates the deterioration of the tax base. This second mechanism is not present in the model without home production.

As seen in the above, the effects of home production are not limited only to the consumption Laffer curve. Also income Laffer curves exhibit different behavior with home production. The intuition behind the result is similar to that of the consumption Laffer curve. An increase in income tax rate, be it capital or labor tax, lowers the disposable income and, thus, has a direct effect on labor supply. At the same time, the relative prices of consumption and leisure change induce a decrease in market-based consumption and an increase in home production. The mechanism is such that it amplifies the negative tax revenue effect of taxation. Another angle of the same mechanism is that inclusion of home production makes labor supply more responsive to taxation. This is the argument also made by Rupert et al. (2000).

It's unclear why Vogel (2012) doesn't basically find any effects (in the benchmark calibration) because of home production compared to a model without this mechanism. The particular model is much more complicated, and therefore, the relevant mechanism is somewhat blurred by other effects. This is one of the contributions of this paper: to build a model comparable to the Trabandt and Uhlig (2011) model and augment the model only with home production, thus, isolating away all the other potentially intervening effects.

\subsection{Tax Revenue Maximizing Tax Mix}

The previous subsection calculated the Laffer curves when one tax rate at a time was varied. In this section, a more general approach is taken; all tax rates are allowed to vary between $0 \%$ and $100 \%$, and the tax revenue maximizing tax mix is calculated. Once again, the analysis is of tax revenue doesn't take welfare implications into consideration.

First, the tax revenue maximizing capital tax rate is zero if other tax rates are free to adjust. This observation is verified by numerical calculations.

Next, the Iso Tax Revenue Curves are plotted in Figure 5 when capital income tax rate is set to zero. Revenue maximizing tax mix with home production is found to be $\left\{\tau^{c}, \tau^{n}, \tau^{k}=100 \%, 9 \%, 0 \%\right\}$. The corresponding tax mix without home production is $\left\{\tau^{c}, \tau^{n}, \tau^{k}=\right.$ $100 \%, 42 \%, 0 \%\}$. The introduction and modeling of home production, thus, implies lower labor income tax in the tax revenue maximizing tax mix, and therefore, less fiscal space. The revenue maximizing tax mix reflects the 
somewhat common result that consumption taxation is the most efficient tax form to collect taxes in this type of models. The "efficiency of consumption taxation" can also be seen using equation (8). Assuming exogenous $w_{t}$, taxation distorts the optimal labor supply decision by the factor $\frac{1-\tau^{n}}{1+\tau^{c}}$, which, in turn, implies that, for example, 30\% labor income tax rate is as distorting as $43 \%$ consumption tax rate and so forth. ${ }^{7}$

The Iso Tax Revenue Curves in Figure 5 are plotted so that each curve to the right is at $10 \%$ lower aggregate tax revenue level. This illustrates the trade-off in tax revenue between the two plotted tax rates. An identical aggregate tax revenue, 0.7 of maximum, for instance, can be collected when $\left\{\tau^{n}, \tau^{c}\right\}=\{0 \%, 55.8 \%\}$, when $\left\{\tau^{n}, \tau^{c}\right\}=$ $\{43.0 \%, 16.4 \%\}$, or when $\left\{\tau^{n}, \tau^{c}\right\}=\{50.4 \%, 100.0 \%\}$.

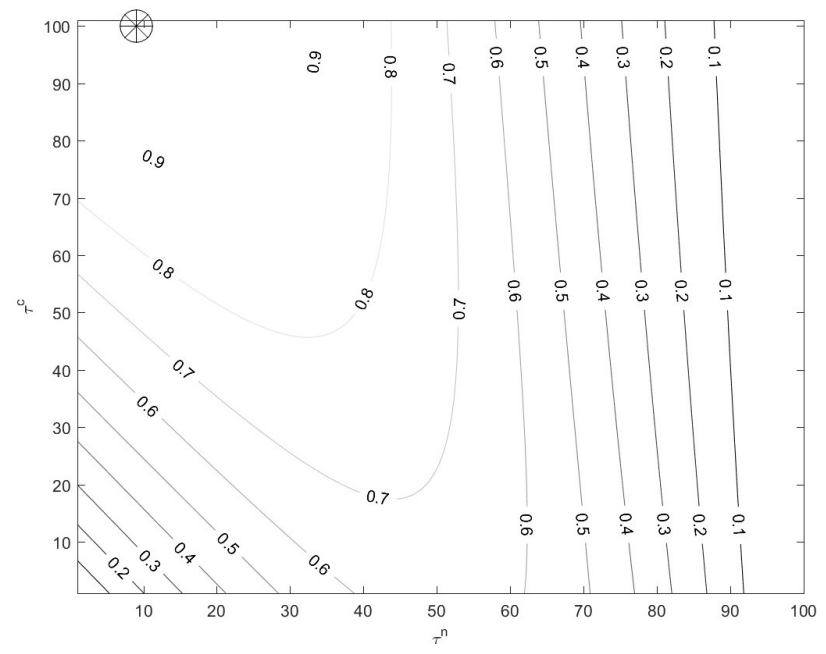

Figure 5: Iso Tax Revenue Curves when $\tau^{k}=0$

Figure 5 also reveals that given a consumption tax rate of $20 \%$, for instance, a 0.6 aggregate tax revenue can be achieved by setting $\tau^{n}$ to approximately $20 \%$ or to $61 \%$. This implies that the $\left\{\tau^{n}, \tau^{c}\right\}=\{20 \%, 61 \%\}$ tax mix is on the slippery side of the Laffer curve and a decrease in labor income tax rate would lead to, ceteris paribus, an increase in aggregate tax revenue. Furthermore, the Figure 5 actually reveals all tax rate combinations that are on the slippery side of the Laffer curve.

$7 \frac{1-30 \%}{1+0 \%} \approx \frac{1-0 \%}{1+43 \%}$

\section{Sensitivity Analysis}

How do the calibrated parameter values affect the results? It is known that the assumptions made make the results, thus, a comprehensive sensitivity analysis is very important, even though the focus in this paper is not on the quantitative results, but instead in the introduction of a new, previously lacking mechanism to the model.

Fiscal space increases when the Laffer peak moves to the right; the set of reasonable choices grows when the objective is to collect more tax revenue. The movement of the Laffer peak is not, in any way, a statement of welfare but merely a interpretation of the fiscal environment conditional on the relevant parameter values. In this section, the underlying assumptions of the model framework are tested. Sensitivity testing also sheds light on the dynamics of the model. Table 4 reports the results of sensitivity analysis. The first row reports the tax revenue maximizing tax rates in the benchmark model with home production. In general, the qualitative results are very robust to the calibration of the model.

Table 4: Sensitivity of the Model with Home Production

\begin{tabular}{lccccc}
\hline Parameter & Baseline & Modified & \multicolumn{3}{c}{ Laffer Peak } \\
& value & value & $\tau^{n}$ & $\tau^{c}$ & $\tau^{k}$ \\
\hline Baseline & \multicolumn{7}{c}{$35 \%$} & $60 \%$ & $0 \%$ \\
& \multicolumn{5}{c}{ Behavioral parameters } \\
\hline$\sigma$ & 2 & 0.5 & $+4 \%$ & $+11 \%$ & $0 \%$ \\
$\beta$ & 0.969 & 0.95 & $0 \%$ & $-5 \%$ & $0 \%$ \\
$\phi$ & 0.82 & 0.1 & $+5 \%$ & $+12 \%$ & $+2 \%$ \\
$\kappa$ & 0.5 & 0.4 & $+1 \%$ & $+33 \%$ & $0 \%$ \\
\multicolumn{7}{c}{ Firm level parameters } \\
\hline$g^{A}$ & 0.009 & 0.02 & $-2 \%$ & $-8 \%$ & $0 \%$ \\
$\delta$ & 0.06 & 0.09 & $0 \%$ & $-8 \%$ & $0 \%$ \\
\hline \multicolumn{7}{c}{ The government } \\
$b / y$ & 0.243 & 0.3 & $0 \%$ & $-9 \%$ & $0 \%$ \\
\hline$/ y$ & 0.493 & 0.8 & $0 \%$ & $0 \%$ & $0 \%$ \\
\hline \multicolumn{7}{c}{}
\end{tabular}

A decrease in $\sigma$ implies higher intertemporal elasticity of substitution. Individuals wish to supply more capital into the market as they are more willing to substitute today's consumption into tomorrow's. The labor tax base becomes less responsive and as a result, the Laffer peak moves to the right - fiscal space increases. A decrease in $\beta$ has similar effect to an increase in $\sigma$ in terms of consumption tax Laffer curve.

It has been argued that the elasticity of labor supply would be small, even close to zero for certain groups. The 
behavioral parameter determining the elasticity of labor supply, $\phi$, has important implications on the shape of the Laffer curve. If the elasticity of labor supply was considerably lower, 0.1 instead of 0.82 , the fiscal space would increase by $5 \mathrm{pp}$. in labor income taxation and $12 \mathrm{pp}$. in consumption taxation. Lower labor supply elasticity implies lower dead-weight loss of taxation, and consequently, an economy can uphold a higher tax rate with smaller negative effects. Interestingly, a low labor supply elasticity also makes the case for strictly positive linear capital taxation (in the tax-revenue maximizing sense) as the negative effect of capital tax on labor supply is muted.

As stated earlier, the consumption substitution parameter, $\kappa$, is rather important parameter in terms of results. The higher the value of this parameter, the lower is the substitution elasticity between market-produced goods and home-produced goods. A decrease in $\kappa$ makes consumption more sensitive to a consumption tax change, because the adjustment in consumption is realized mostly through home production - larger substitution elasticity in consumption is equivalent to larger fiscal space in consumption taxation.

An increase in exogenous growth rate of the economy, $\gamma^{A}$, or capital depreciation rate, $\delta$, shift the Laffer curve to the left, thus, diminishing fiscal space. Finally, the level of public debt has no effect on the shape of the Laffer curve - debt has no effect on individual behavior and, thus, doesn't change the shape of any Laffer curve. The story with government consumption is slightly different in terms of consumption Laffer curve. A ceteris paribus increase in $g_{t}$ forces government budget constraint to adjust either through transfers $\left(s_{t}\right)$ or through behavioral response. The amount of transfers decreases resulting in lower (private) consumption opportunities, which in turn induces individuals to supply more labor into the market (income effect). In the aggregate, increase in $g_{t}$ leads to higher labor supply, lower private consumption, and, in the end, lower aggregate tax accrual because the consumption response is clearly larger than the change in labor income tax base. At the end of the day, fiscal space has grown smaller and, consequently, the consumption Laffer peak has moved to the left.

\section{Conclusions}

Using a standard neoclassical growth model of general equilibrium, it is shown that the inclusion of home production has significant implications on tax policy. In a standard model (no home production), an increase in the consumption tax rate has an effect on labor supply but it doesn't change the composition of consumption, as there is only one consumable good. In a corresponding model with home production, an increase in consumption tax rate, additionally, shifts more weight from consumption of market-based goods to consumption of home-produced goods. Most models of general equilibrium do not take this channel seriously.

This mechanism, generated by the inclusion of home production, makes the consumption tax base more sensitive to a change in the tax rate. The deterioration of consumption tax base because of a tax hike is more pronounced because individuals substitute consumption of market goods with home production.

The implication in terms of tax policy is that if indeed home production is a genuine substitute for market consumption, tax revenue estimates produced by standard models are too optimistic. Consequently, the estimated revenue maximizing (steady state) tax rates in previous studies are possibly too high. As is shown in this paper, the policy implication can be drastic.

We can think through the lens of a model without home production that the economy is located on the left side of the Laffer peak, meaning that an increase in a tax rate increases tax revenues. In certain cases, it might then be optimal to increase the taxation in order to generate more tax revenue for the government to use. If, however, the model takes home production into account, the same economy could be located on the "wrong" side of the Laffer peak and the only reasonable policy advice would then be to lower the level of taxation in the long run in all possible instances. Fiscal space has turned into a fiscal gap when the model is augmented in certain way.

The analysis in this paper concentrates on comparing different steady states. This is not to say that transitional dynamics were not important, but it is outside the scope of this paper and left for future research.

The main objective of this paper is not to give exact quantitative estimates of the Laffer curve but instead to point out that the introduction of a simple and well-known mechanism can turn the policy advice of a "traditional model" upside down. One topic of future research is to explore the relationship between home production and tax policies with quality data and setup that allows for credible causal inferences. 


\section{References}

Aguiar, M. A., Hurst, E. and Karabarbounis, L. (2011) Time Use During Recessions, NBER Working Papers 17259, National Bureau of Economic Research, Inc.

Auray, S., Eyquem, A. and Gomme, P. (2015) A Tale of Tax Policies in Open Economies, Working Papers 11004, Concordia University, Department of Economics.

Baxter, M. and King, R. G. 1993 Fiscal Policy in General Equilibrium, The American Economic Review, Vol. 83, No. 3 (Jun., 1993), 315334.

Chang, Y., and Schorfheide F. (2003) Labor Supply Shifts and Economic Fluctuations, Journal of Monetary Economics 50, 1751-1768.

Chetty, R., Guren, A., Manoli, D. and Weber, A. (2011) Are Micro and Macro Labor Supply Elasticities Consistent? A Review of Evidence on the Intensive and Extensive Margins, American Economic Review, American Economic Association, vol. 101(3), pages 471-75, May.

Cooley, T. F. and Soares, J. 1999 Privatizing Social Security, Review of Economic Dynamics 2, 731-755.

Engström, P., Holmlund, P. and Kolm, A. (2001) Optimal Taxation in Search Equilibrium with Home Production, CESifo Working Paper Series 613, CESifo Group Munich.

European Commission (2015) The 2015 Ageing Report: Economic and budgetary projections for the 28 EU Member States (2013-2060), European Economy. 3. May 2015. Brussels.

Feve, P., Matheron, J., Sahuc, J. 2013 The Laffer Curve in an Incomplete-market Economy, IDEI Working Papers No. 707.

Hiraga, K. and Nutahara, K. (2016) When is the Laffer Curve for Consumption Tax Hump-Shaped?, CIGS Working Paper Series No. 16002E.

Holmlund, B. (2002) Labor Taxation in Search Equilibrium with Home Production, German Economic Review, Verein für Socialpolitik, vol. 3(4), pages 415-430, November.

Holter, H. A., Krueger, D., Stepanchuk, S. (2014) How Does Tax Progressivity and Household Heterogeneity Affect Laffer Curves, NBER Working Paper 20688.

Keane, M. and Rogerson, R. (2012) Micro and MAcro Labor Supply Elasticities: A Reassessment of Conventional Wisdom, Journal of Economic Literature 2012, 50:2, 464-476.
Kotamäki, M. (2015) What is the Fiscal Position in Finland? Laffer Curves Calculated, Ministry of Finance Discussion Papers.

McGrattan, E., Rogerson R., and Wright R. (1997) An Equilibrium Model of the Business Cycle with Household Production and Fiscal Policy, International Economic Review 38, 267-290.

Mendoza, E. G., Razin, A. and Tesar, L. L. (1994) Effective tax rates in macroeconomics: cross-country estimates of tax rates on factor incomes and consumption, Journal of Monetary Economics 34, 297-323.

Nutahara, K. (2013) Laffer Curves in Japan, CIGS Working Paper Series No. 13-007(E).

Olovsson, C. (2009) Why Do Europeans Work So Little?, International Economic Review Vol. 50, No. 1, February 2009.

Olovsson, C. (2015) Optimal taxation with home production, Journal of Monetary Economics 70 (2015) 39-50.

Papageorgiou, D.(2012) Fiscal policy reforms in general equilibrium: The case of Greece. Journal of Macroeconomics 34 (2012) 504-522.

Prescott, E. C. (2004) Why Do Americans Work so Much More than Europeans?, Federal Reserve Bank of Minneapolis Quarterly Review 28, 2004.

Rogerson, R. and Wallenius, J. (2012) Retirement, Home Production and Labor Supply Elasticities, 2012 Meeting Papers 41, Society for Economic Dynamics.

Rupert, P., Rogerson, R. and Wright, R. (2000) Homework in labor economics: Household production and intertemporal substitution, Journal of Monetary Economics 46 (2000) 557-579.

Trabandt, M., Uhlig, H. (2011) The Laffer Curve Revisited. Journal of Monetary Economics 58(4) 305-27.

Trabandt, M., Uhlig, H. (2012) How Do Laffer Curves Differ Across Countries? NBER Working Paper 17862.

Vogel, L. (2012) Tax Avoidance and fiscal limits: Laffer curves in an economy with informal sector, European Economy Economic Papers 448, January 2012.

Zanetti, F. (2012) The Laffer Curve in a Frictional Labor Market, The B.E. Journal of Macroeconomics: Vol. 12: Iss. 1 (Topics), Article 29.

Salanie, B. (2002) The Economics of Taxation, the MIT Press, Cambridge, Massachusetts. 